\title{
Crystal Chemistry and Properties of Elpidite and Its Ag-Exchanged Forms
}

\author{
Natalia V. Zubkova ${ }^{1, *}$, Rositsa P. Nikolova ${ }^{2}{ }^{(\mathbb{C}}$, Nikita V. Chukanov ${ }^{3}$, \\ Vladislav V. Kostov-Kytin ${ }^{2}{ }^{\circledR}$, Igor V. Pekov ${ }^{1}$, Dmitry A. Varlamov ${ }^{3,4}{ }^{\circledR}$, Tatiana S. Larikova ${ }^{3}$, \\ Olga N. Kazheva ${ }^{3}$, Nadezhda A. Chervonnaya ${ }^{3}$, Gennadiy V. Shilov ${ }^{3}$ and \\ Dmitry Yu. Pushcharovsky ${ }^{1}$ \\ 1 Faculty of Geology, Moscow State University, Vorobievy Gory, 119991 Moscow, Russia \\ 2 Institute of Mineralogy and Crystallography, Bulgarian Academy of Sciences, 1113 Sofia, Bulgaria \\ 3 Institute of Problems of Chemical Physics, Russian Academy of Sciences, 142432 Chernogolovka, \\ Moscow Region, Russia \\ 4 Institute of Experimental Mineralogy, Russian Academy of Sciences, 142432 Chernogolovka, \\ Moscow Region, Russia \\ * Correspondence: n.v.zubkova@gmail.com; Tel.: +7-910-469-5884
}

Received: 17 June 2019; Accepted: 5 July 2019; Published: 10 July 2019

\begin{abstract}
Elpidite from the Lovozero alkaline complex, Kola Peninsula, Russia, and Ag-exchanged forms of elpidite from two different localities (Lovozero and Khan Bogdo, Mongolia) were studied by means of single-crystal X-ray diffraction, electron microprobe analysis, thermogravimetry and IR spectroscopy. All studied samples retain the heteropolyhedral framework consisting of double $\mathrm{Si}_{6} \mathrm{O}_{15}$ chains (ribbons) and isolated $\mathrm{ZrO}_{6}$ octahedra. Zeolitic cavities in the initial elpidite from Lovozero (space group Pbm2, $a=14.6127(7), b=7.3383(4), c=7.1148(3) \AA, V=762.94(6) \AA^{3}$ ) are occupied by $\mathrm{Na}^{+}$cations and $\mathrm{H}_{2} \mathrm{O}$ molecules. Both Ag-exchanged forms are characterized by evident distortions of the heteropolyhedral framework and a strongly disordered arrangement of extra-framework cations which results in the appearance of the 14-14-14 $\AA$ unit cell ( $a=14.1755(7)$, $b=14.6306(9), c=14.2896(7) \AA, V=2963.6(3) \AA^{3}$ for the Ag-exchanged form of elpidite from Lovozero and $a=14.1411(5), b=14.5948(4), c=14.3035(5) \AA, V=2952.04(17) \AA^{3}$ for the Ag-exchanged form of elpidite from Khan Bogdo) and space group Cmce. Elpidite from both localities demonstrates a high exchange capacity to $\mathrm{Ag}$. Exchanged $\mathrm{Ag}^{+}$cations preferably occupy the sites that are close to the $\mathrm{Na}$ sites in the initial elpidite. The paper also contains a review of crystal chemical data on elpidite and its laboratory-modified forms.
\end{abstract}

Keywords: elpidite; microporous zirconosilicate; ion exchange; silver; zeolitic properties; crystal structure; Lovozero alkaline complex; Khan Bogdo alkaline complex; IR spectroscopy; thermogravimetry

\section{Introduction}

Synthetic zeolite-like microporous zirconosilicates with heteropolyhedral frameworks (i.e., frameworks formed by $\mathrm{SiO}_{4}$ tetrahedra and $\mathrm{ZrO}_{6}$ octahedra with the general formula $\left.\left[\mathrm{Zr}_{m} \mathrm{Si}_{n} \mathrm{O}_{3 m+2 n}\right]^{-2 m}\right)$ attract much attention due to the prospects of their wide application in chemical technologies as ion-exchangers, high-selectivity sorbents, catalysts, ion conductors, etc. [1]. Many of these compounds have natural analogues-minerals-and some of them are able to form deposits which are of special interest as the resources of zeolite-like materials of such type.

Elpidite, ideally $\mathrm{Na}_{2} \mathrm{ZrSi}_{6} \mathrm{O}_{15} \cdot 3 \mathrm{H}_{2} \mathrm{O}$, is one of the best examples of such minerals. This zirconosilicate is characterized by strong ion-exchange properties which occur both in laboratory 
conditions [2,3] and in nature [4]. The crystal structure of elpidite was first solved by [5] in the space group Pbmm. Later on, the structure of this mineral was re-refined by different authors, in some cases in the acentric space group Pbm2 [6] or in the space group Pbcm with one unit-cell parameter doubled [7], see Table 1 In all cases, the crystal structure of elpidite is described by a heteropolyhedral framework consisting of double $\mathrm{Si}_{6} \mathrm{O}_{15}$ chains (ribbons) and isolated $\mathrm{ZrO}_{6}$ octahedra. Zeolite cavities inside the heteropolyhedral framework are occupied by $\mathrm{Na}^{+}$cations (usually with minor $\mathrm{Ca}^{2+}$ and $\mathrm{K}^{+}$admixtures) and $\mathrm{H}_{2} \mathrm{O}$ molecules [7]. Ca-enriched variety of elpidite and its dehydrated product were also studied $[8,9]$. Previously, we reported the crystal structures of the product of elpidite dehydration in laboratory conditions, an anhydrous $\mathrm{Na}_{2} \mathrm{ZrSi}_{6} \mathrm{O}_{15}$ (obtained from an elpidite sample from the Lovozero alkaline massif, Kola Peninsula, Russia) [10], as well as Rb-exchanged forms of elpidite $\mathrm{Na}_{1.58} \mathrm{Rb}_{0.20} \mathrm{H}_{0.22} \mathrm{Zr}\left(\mathrm{Si}_{6} \mathrm{O}_{15}\right) \cdot 2.69 \mathrm{H}_{2} \mathrm{O}$ and $\mathrm{Rb}_{1.78} \mathrm{Na}_{0.06} \mathrm{H}_{0.16} \mathrm{Zr}\left(\mathrm{Si}_{6} \mathrm{O}_{15}\right) \cdot 0.90 \mathrm{H}_{2} \mathrm{O}$ (obtained at 90 and $150{ }^{\circ} \mathrm{C}$, respectively) and $\mathrm{K}$-exchanged forms $\mathrm{K}_{1.78} \mathrm{Na}_{0.16} \mathrm{H}_{0.06} \mathrm{Zr}\left(\mathrm{Si}_{6} \mathrm{O}_{15}\right) \cdot 0.85 \mathrm{H}_{2} \mathrm{O}$ and $\mathrm{K}_{1.84} \mathrm{Na}_{0.11} \mathrm{H}_{0.05} \mathrm{Zr}\left[\mathrm{Si}_{6} \mathrm{O}_{15}\right] \cdot 0.91 \mathrm{H}_{2} \mathrm{O}$ (obtained at $90^{\circ} \mathrm{C}$ and $150{ }^{\circ} \mathrm{C}$, respectively) [3], (obtained from an elpidite sample from Khan Bogdo, Mongolia). For the dehydration product of elpidite, its K-exchanged forms obtained at $90^{\circ} \mathrm{C}$ and $150{ }^{\circ} \mathrm{C}$ and $\mathrm{Rb}$-exchanged form obtained at $150{ }^{\circ} \mathrm{C}$, doubling of the unit cell in comparison with the elpidite model by [7] and space group Cmce were revealed. The authors of [11] studied an elpidite sample from the Mont Saint-Hilaire massif (Poudrette quarry, QC, Canada) and its partially and completely dehydrated forms. This study was performed between $25^{\circ} \mathrm{C}$ and $350{ }^{\circ} \mathrm{C}$ under different humidity conditions and showed that, under dry conditions, dehydration started at $75{ }^{\circ} \mathrm{C}$. At $100{ }^{\circ} \mathrm{C}$, one $\mathrm{H}_{2} \mathrm{O}$ molecule was lost and a structural change accompanied by a change from space group $\mathrm{Pbcm}$ to $\mathrm{Cmce}$ was observed. Further immersion of a dehydrated sample in water led to marginal rehydration, however, the space group Cmce was preserved [11]. Previously, the two-stage process of elpidite dehydration was reported, based on thermogravimetric and IR spectroscopic data $[10,12]$. A monoclinic (with $\beta$ close to $90^{\circ}$ ) mineral species closely related to elpidite, yusupovite $\mathrm{Na}_{2} \mathrm{ZrSi}_{6} \mathrm{O}_{15} \cdot 2.5 \mathrm{H}_{2} \mathrm{O}$ which contains $\mathrm{K}$ and $\mathrm{Cs}$ impurities, was recently studied. Due to (K,Cs), $\mathrm{Na}$ and $\mathrm{H}_{2} \mathrm{O}$ disorder, the symmetry of yusupovite decreases from orthorhombic to monoclinic (space group $\mathrm{C2} / \mathrm{m}$ ) with doubling of unit-cell parameters which are close to those found for dehydrated elpidite and some cation-exchanged forms of the mineral [13]. 
Table 1. Some crystallographic data for elpidite, related mineral yusupovite and laboratory-modified forms of elpidite.

\begin{tabular}{|c|c|c|c|c|c|c|}
\hline Sample/Locality & Sp.gr., Z & $a(\AA)$ & $b(\AA)$ & $c(\AA)$ & $V\left(\AA^{3}\right)$ & Ref. \\
\hline Elpidite/Lovozero, Kola peninsula, Russia & Pbmm, 2 & 7.4 & 14.4 & 7.05 & 751.3 & [5] \\
\hline Elpidite/Lovozero, Kola peninsula, Russia & $P b m 2,2$ & 7.4 & 14.4 & 7.05 & 751.3 & {$[6]$} \\
\hline Elpidite/Mont Saint-Hilaire, Québec, Canada & Pbcm, 4 & $7.14(2)$ & $14.68(1)$ & 14.65(1) & 1535.5 & [7] \\
\hline Elpidite (Ca-enriched variety)/Khan Bogdo, Mongolia & $P b m 2,2$ & 7.31 & 14.68 & 7.13 & 765.1 & [8] \\
\hline Elpidite (Ca-enriched variety), dehydrated/init. Khan Bogdo, Mongolia & $B b a 2,8$ & 14.48 & 14.28 & 14.09 & 2913.5 & [9] \\
\hline Elpidite/Lovozero, Kola peninsula, Russia & $\mathrm{Pbcm}, 4$ & $7.1136(1)$ & $14.6764(2)$ & $14.5977(2)$ & $1524.02(4)$ & {$[10]$} \\
\hline Elpidite, dehydrated/init. Lovozero, Kola peninsula, Russia & Cmce, 8 & 14.0899(1) & $14.4983(1)$ & $14.3490(1)$ & 2931.23(4) & [10] \\
\hline Elpidite/Khan Bogdo, Mongolia & $\mathrm{Pbcm}, 4$ & $7.1312(12)$ & $14.6853(12)$ & $14.6349(15)$ & $1532.6(3)$ & [3] \\
\hline K-exch. $\left(90^{\circ} \mathrm{C}\right) /$ init. Khan Bogdo, Mongolia & Cmce, 8 & $14.054(3)$ & 14.308(3) & $14.553(3)$ & $2926.4(11)$ & {$[3]$} \\
\hline K-exch. $\left(150^{\circ} \mathrm{C}\right) /$ init. Khan Bogdo, Mongolia & Cmce, 8 & 14.037(3) & $14.266(3)$ & $14.552(3)$ & 2914.1(11) & [3] \\
\hline Rb-exch. $\left(90^{\circ} \mathrm{C}\right) /$ init. Khan Bogdo, Mongolia & $\mathrm{Pbcm}, 4$ & $7.1280(10)$ & 14.644(3) & $14.642(3)$ & $1528.4(5)$ & [3] \\
\hline Rb-exch. $\left(150^{\circ} \mathrm{C}\right) /$ init. Khan Bogdo, Mongolia & Cmce, 8 & $14.2999(12)$ & $14.4408(15)$ & $14.7690(12)$ & $3049.8(5)$ & [3] \\
\hline Yusupovite/Darai-Pioz, Tajikistan & $C 2 / m, 8$ & $14.5975(4)$ & $\begin{array}{c}14.1100(4) \\
\beta 90.0399(4)^{\circ}\end{array}$ & $14.4394(4)$ & 2974.1(3) & [13] \\
\hline Elpidite/Mont Saint-Hilaire, Québec, Canada & $\mathrm{Pbcm}, 4$ & $7.11340(10)$ & $14.6796(2)$ & $14.6030(2)$ & $1524.87(4)$ & [11] \\
\hline Elpidite, partially dehydrated/Mont Saint-Hilaire, Québec, Canada & Cmce, 8 & $14.1260(5)$ & $14.5734(5)$ & $14.3627(5)$ & 2956.76(18) & [11] \\
\hline Elpidite, dehydrated/Mont Saint-Hilaire, Québec, Canada & Cmce, 8 & $14.1271(4)$ & $14.5110(4)$ & $14.3533(4)$ & 2942.40(14) & [11] \\
\hline Elpidite/Lovozero, Kola peninsula, Russia & $P b m 2 * 2$ & $7.3383(4)$ & $14.6127(7)$ & $7.1148(3)$ & $762.94(6)$ & This work \\
\hline Ag-exch. I/init. Lovozero, Kola peninsula, Russia & Cmce, 8 & $14.1755(7)$ & $14.6306(9)$ & $14.2896(7)$ & $2963.6(3)$ & This work \\
\hline Ag-exch. II/init. Khan Bogdo, Mongolia & Cmce, 8 & $14.1411(5)$ & $14.5948(4)$ & $14.3035(5)$ & 2952.04(17) & This work \\
\hline
\end{tabular}

* The unit cell was transformed from the standard setting Pma2 for more convenient comparison with previous data; init.: the locality of initial sample, for the laboratory-modified form of the mineral. 
Here, we report new data for elpidite from a low-temperature hydrothermal association at Mount Alluaiv in the Lovozero alkaline massif (Kola Peninsula, Russia) and Ag-exchanged forms of elpidite from the same locality (Sample I), in addition to new data from a pegmatite related to alkaline granites of the Khan Bogdo alkaline massif (Southern Gobi, Mongolia) (Sample II). For crystal data of all the above-mentioned samples see Table 1 . Information on the localities at which initial samples were collected is available on the websites https://www.mindat.org/loc-30970.html (for the sample from Lovozero) and https://www.mindat.org/loc-2384.html (for the sample from Khan Bogdo).

\section{Materials and Methods}

The Lovozero sample of elpidite originates from the Elpiditovoe pegmatite uncovered at the Umbozero loparite mine in the western part of Mount Alluaiv. This pegmatite is described in detail in [14]. Elpidite forms open-work aggregates of white columnar crystals up to $10 \mathrm{~cm}$ long associated with natrolite, albite, caryochroite, pyrite and bitumen in miarolitic cavities of the pegmatite.

The studied sample from Khan Bogdo (provided by I.E. Proshenkin) contains brick-red coarse-prismatic grains of elpidite up to $5 \mathrm{~cm}$ across embedded in alkaline-granitic pegmatite mainly consisting of potassic feldspar, aegirine and quartz.

Hydrothermal ion-exchange reactions for the samples I and II were carried out in Teflon-lined steel autoclaves that had an approximately $10 \mathrm{~mL}$ capacity. In a typical synthesis, $0.05 \mathrm{~g}$ of elpidite crystals with sizes ranging from 1 to $2 \mathrm{~mm}$ were mixed with $5 \mathrm{~mL}$ of $1 \mathrm{M} \mathrm{AgNO}_{3}$ solution and $30 \mathrm{~mL}$ of $0.1 \mathrm{M} \mathrm{AgNO}_{3}$ solution, respectively, and were placed in autoclaves and heated for 3 days at $90{ }^{\circ} \mathrm{C}$. The products were carefully washed free from entrained salts and dried at $60{ }^{\circ} \mathrm{C}$ before further investigations.

Chemical data for all samples except the initial elpidite from Lovozero were obtained by means of a Tescan VEGA-II XMU INCA Energy 450 (TESCAN, Brno, Czech Republic) (EDS mode, 20 kV, 190 pA, $180 \mathrm{~nm}$ beam diameter, excitation zone of 3-4 $\mu \mathrm{m}$ ). The following standards were used: albite for $\mathrm{Na}$, orthoclase for $\mathrm{K}$, wollastonite for $\mathrm{Ca}$, quartz for $\mathrm{Si}$, and pure elements for $\mathrm{Ag}$ and $\mathrm{Zr}$. Chemical data for the initial elpidite from Lovozero were taken from [10] as the studied sample was a part of the same crystal as used in [10].

In order to obtain IR absorption spectra, powdered samples were mixed with anhydrous $\mathrm{KBr}$, pelletized, and analyzed using an ALPHA FTIR spectrometer (Bruker Optics, Karlsruhe, Germany) at a resolution of $4 \mathrm{~cm}^{-1}$. A total of 16 scans were collected for each spectrum. The IR spectrum of an analogous pellet of pure KBr was used as a reference. The software OPUS4 (University of Stuttgart, Stuttgart, Germany) applied to the spectrometer was used for processing the spectra.

Thermogravimetric data were obtained in the temperature range $20-550{ }^{\circ} \mathrm{C}$, at a heating rate of $6^{\circ} \mathrm{C} / \mathrm{min}$ using a thermobalance ATV-14M (Institute of Problems of Chemical Physics, Chernogolovka, Russia). Rehydration kinetics of partly (50\%) and completely dehydrated samples from Lovozero kept at room temperature in a humid air atmosphere (with a 100\% relative humidity) were obtained, followed by weighing.

Initial elpidite from Lovozero and both Ag-exchanged samples were studied using the single-crystal XRD technique. The measured intensities were corrected for Lorentz, background, polarization and absorption effects. Data reduction was performed using CrysAlisPro Version 1.171.37.35 for the elpidite sample from Lovozero alkaline massif and its Ag-exchanged form [15] and CrysAlisPro Version 1.171.39.46 [16] for the Ag-exchanged form of elpidite from Khan Bogdo. The unit-cell parameters of our elpidite from Mount Alluaiv (Lovozero) are close to those reported earlier for elpidite from another locality in the same Lovozero massif in [6], and the unit-cell parameters of both our Ag-exchanged forms are close to those obtained for the dehydration product of elpidite and its K-exchanged $\left(\right.$ at $90^{\circ} \mathrm{C}$ and $150^{\circ} \mathrm{C}$ ) and $\mathrm{Rb}$-exchanged (at $150{ }^{\circ} \mathrm{C}$ ) forms. The crystal structures of all studied samples were obtained using direct methods and refined using the SHELX software package [17]. In the structure of our initial elpidite from Lovozero, the positions of $\mathrm{H}$ atoms were fixed. Ow1, $\mathrm{H} 1 \mathrm{a}$ and $\mathrm{H} 1 \mathrm{~b}$ were refined as a rigid group; Ow2-H2 distances were softly restrained at $0.85(1) \AA$ and $\mathrm{H} 2-\mathrm{H} 2$ distance at $1.37(2) \AA$ 
to hold near-optimal geometry and for both water molecules $U_{\text {iso }}(\mathrm{H})=1.5 U_{\mathrm{eq}}(\mathrm{O})$. The crystal data and the experimental details are presented in Table 2. The structures were deposited with CCDC with CSD deposition numbers 1937293 (initial elpidite from Lovozero), 1937294 (sample I) and 1937295 (sample II).

Table 2. Crystal data, data collection information and structure refinement details for elpidite from Lovozero and Ag-exchanged samples I and II.

\begin{tabular}{|c|c|c|c|}
\hline Sample & Elpidite (Lovozero) & I & II \\
\hline Formula weight* & 599.79 & 734.72 & 711.78 \\
\hline Temperature, K & \multicolumn{2}{|c|}{ 293(2) } & $150.0(1)$ \\
\hline Radiation and wavelength, $\AA$ & \multicolumn{3}{|c|}{$\operatorname{MoK} \alpha ; 0.71073$} \\
\hline Crystal system, space group, $Z$ & Orthorhombic, Pma2 **, 2 & \multicolumn{2}{|c|}{ Orthorhombic, Cmce, 8} \\
\hline & $a=14.6127(7)$ & $a=14.1755(7)$ & $a=14.1411(5)$ \\
\hline Unit-cell dimensions, $\AA$ & $\begin{array}{l}b=7.3383(4) \\
c=7.1148(3)\end{array}$ & $\begin{array}{l}b=14.6306(9) \\
c=14.2896(7)\end{array}$ & $\begin{array}{l}b=14.5948(4) \\
c=14.3035(5)\end{array}$ \\
\hline$V, \AA^{3}$ & $762.94(6)$ & $2963.6(3)$ & $2952.04(17)$ \\
\hline Absorption coefficient $\mu, \mathrm{mm}^{-1} *$ & 1.35 & 3.85 & 3.59 \\
\hline $\mathrm{F}_{000}$ * & 592 & 2782 & 2702 \\
\hline Crystal size, $\mathrm{mm}$ & $0.12 \times 0.25 \times 0.30$ & $0.007 \times 0.007 \times 0.013$ & $0.10 \times 0.13 \times 0.15$ \\
\hline Diffractometer & \multicolumn{2}{|c|}{ Oxford Diffraction, SuperNova } & Xcalibur S CCD \\
\hline$\theta$ range for data collection, ${ }^{\circ}$ & $2.788-28.769$ & $2.784-28.176$ & $2.881-27.857$ \\
\hline & $-19 \leq h \leq 15$ & $-18 \leq h \leq 18$ & $-18 \leq h \leq 11$ \\
\hline Index ranges & $\begin{array}{l}-9 \leq k \leq 7 \\
-9 \leq l \leq 9\end{array}$ & $\begin{array}{l}-15 \leq k \leq 17 \\
-16 \leq l \leq 18\end{array}$ & $\begin{array}{l}-15 \leq k \leq 19 \\
-15 \leq l \leq 18\end{array}$ \\
\hline Reflections collected & 3681 & 6530 & 4935 \\
\hline Independent reflections & $1653\left(R_{\mathrm{int}}=0.0239\right)$ & $1718\left(R_{\text {int }}=0.0636\right)$ & $1823\left(R_{\mathrm{int}}=0.0202\right)$ \\
\hline Independent reflections $[I>2 \sigma(I)]$ & 1437 & 1195 & 1707 \\
\hline Absorption correction & \multicolumn{3}{|c|}{ Multi-scan } \\
\hline Refinement method & \multicolumn{3}{|c|}{ Full-matrix least-squares on $F^{2}$} \\
\hline Number of refined parameters & 132 & $150^{1}$ & 147 \\
\hline Final $R$ indices $[I>2 \sigma(I)] R 1 / \mathrm{w} R 2$ & $0.0275 / 0.0644$ & $0.0514 / 0.0986$ & $0.0539 / 0.1140$ \\
\hline$R$ indices (all data) $R 1 / \mathrm{w} R 2$ & $0.0349 / 0.0695$ & $0.0871 / 0.1145$ & $0.0581 / 0.1158$ \\
\hline $\mathrm{GoF}$ & 1.158 & 1.045 & 1.201 \\
\hline Largest diff. peak and hole, e/ $/ \AA^{3}$ & 0.805 and -0.495 & 1.282 and -1.401 & 1.357 and -1.486 \\
\hline
\end{tabular}

\section{Results}

\subsection{Chemical Composition}

Representative chemical data are given in Table 3. The formulae of the starting samples are $\left(\mathrm{Na}_{1.98} \mathrm{~K}_{0.01}\right)\left(\mathrm{Zr}_{1.02} \mathrm{Nb}_{0.03} \mathrm{Hf}_{0.01}\right)\left(\mathrm{Si}_{5.92} \mathrm{Al}_{0.02}\right) \mathrm{O}_{15} \cdot 3.40 \mathrm{H}_{2} \mathrm{O}$ (for the sample from Lovozero) and $\mathrm{H}_{0.03}\left(\mathrm{Na}_{1.65} \mathrm{Ca}_{0.15} \mathrm{~K}_{0.01}\right) \mathrm{Zr}_{1.00} \mathrm{Si}_{6.00} \mathrm{O}_{15} \cdot 2.82 \mathrm{H}_{2} \mathrm{O}$. Formula coefficients for Sample I calculated based on $6 \mathrm{Si}$ atoms per formula unit (apfu) are in the following ranges: $\mathrm{Ag}_{1.71-1.84} \mathrm{Na}_{0.16-0.20} \mathrm{Zr}_{0.96-1.02} \mathrm{Si}_{6} \mathrm{O}_{15} \cdot n \mathrm{H}_{2} \mathrm{O}$. Electron microprobe analyses of Sample II revealed two zones (Figure 1) with the compositional ranges $\mathrm{Ag}_{1.97-2.11} \mathrm{Ca}_{0.01-0.05} \mathrm{Na}_{0.00-0.02} \mathrm{Zr}_{0.96-1.09} \mathrm{Si}_{6} \mathrm{O}_{15} \cdot n \mathrm{H}_{2} \mathrm{O}$ (zone 1) and $\mathrm{Ag}_{1.24-1.30} \mathrm{Ca}_{0.35-0.44} \mathrm{Na}_{0.00-0.05} \mathrm{Zr}_{0.98-1.03} \mathrm{Si}_{6} \mathrm{O}_{15} \cdot n \mathrm{H}_{2} \mathrm{O}$ (zone 2). Ion exchange in Sample II was accompanied by migration of $\mathrm{Ca}^{2+}$ cations and their accumulation in some zones. As a result, these zones became less active towards ion exchange with $\mathrm{Ag}^{+}$. 
Table 3. Chemical composition (wt. \%) of initial and Ag-exchanged elpidite samples.

\begin{tabular}{|c|c|c|c|c|c|c|c|c|}
\hline \multirow{2}{*}{$\begin{array}{l}\text { Component } \\
\mathrm{Na}_{2} \mathrm{O}\end{array}$} & \multirow{2}{*}{$\begin{array}{c}\begin{array}{c}\text { Elpidite } \\
\text { Lovozero } \\
\text { (after [10]) }\end{array} \\
10.17\end{array}$} & \multirow{2}{*}{$\begin{array}{c}\text { Elpidite } \\
\text { Khan } \\
\text { Bogdo }\end{array}$} & \multicolumn{2}{|c|}{ Sample I } & \multicolumn{2}{|c|}{ Sample II, zone 1} & \multicolumn{2}{|c|}{ Sample II, zone 2} \\
\hline & & & 0.64 & 0.87 & 0 & 0.08 & 0 & 0.22 \\
\hline $\mathrm{CaO}$ & - & 1.41 & - & - & 0.07 & 0.35 & 3.46 & 2.81 \\
\hline $\mathrm{Ag}_{2} \mathrm{O}$ & - & - & 28.22 & 26.73 & 29.87 & 31.81 & 20.28 & 21.25 \\
\hline $\mathrm{ZrO}_{2}$ & 20.89 & 20.94 & 16.63 & 15.94 & 17.19 & 15.34 & 17.89 & 17.04 \\
\hline $\mathrm{SiO}_{2}$ & 59.02 & 61.05 & 47.61 & 48.67 & 46.08 & 46.94 & 50.94 & 50.83 \\
\hline Total & $91.32 *$ & $92.12^{* *}$ & 93.10 & 92.21 & 93.21 & 94.52 & 92.57 & 92.15 \\
\hline $\begin{array}{c}\mathrm{H}_{2} \mathrm{O} \text { (by TG } \\
\text { data) }\end{array}$ & 10.16 & 8.43 & \multicolumn{2}{|c|}{7.00} & \multicolumn{4}{|c|}{7.49} \\
\hline
\end{tabular}

* The total includes $0.04 \% \mathrm{~K}_{2} \mathrm{O}, 0.15 \% \mathrm{Al}_{2} \mathrm{O}_{3}, 0.43 \% \mathrm{HfO}_{2}$ and $0.62 \% \mathrm{Nb}_{2} \mathrm{O}_{5}$. ${ }^{* *}$ The total includes $0.08 \% \mathrm{~K}_{2} \mathrm{O}$.

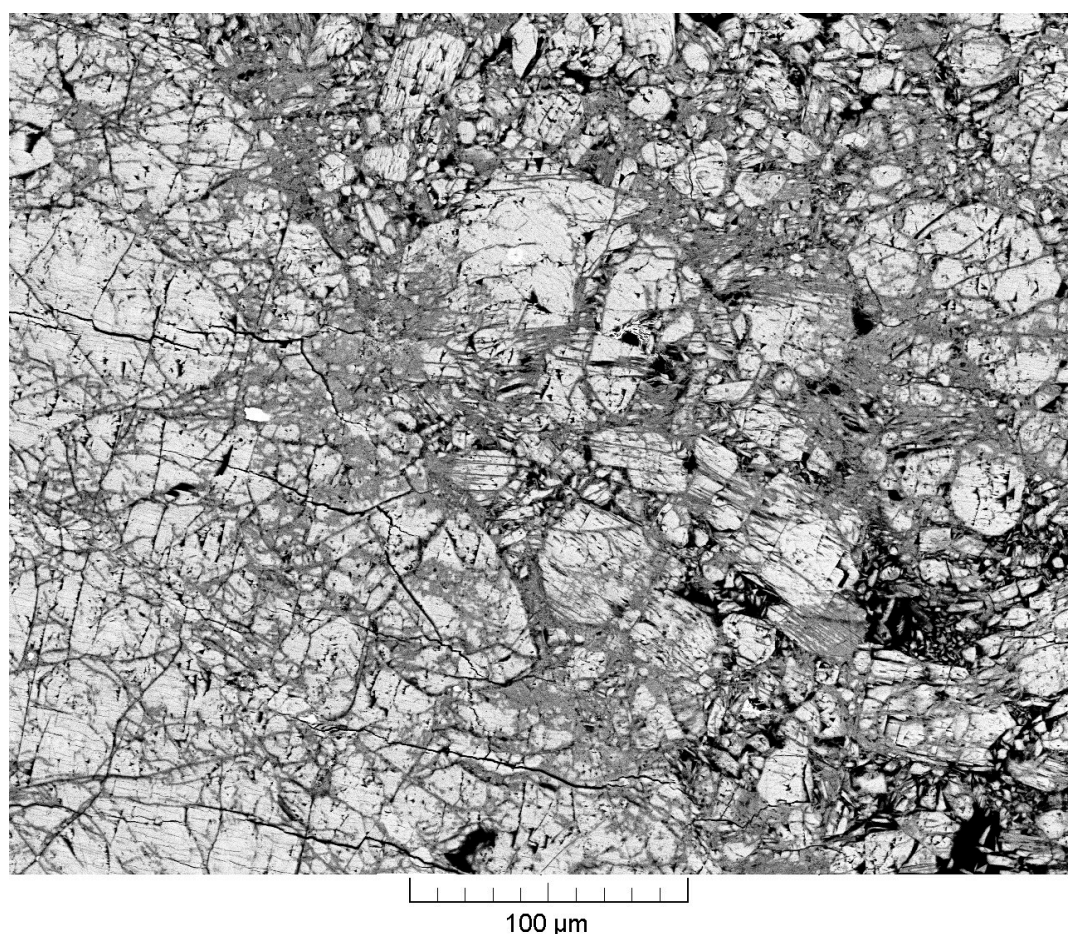

Figure 1. Image of Sample II in back-scattered electrons. The zones 1 and 2 are light gray and dark gray, respectively.

\subsection{Infrared Specroscopy}

All IR spectra of initial and Ag-exchanged elpidite samples (Figure 2) show absorption bands of stretching and bending vibrations of $\mathrm{H}_{2} \mathrm{O}$ molecules (in the ranges 3200 to 3700 and 1600 to $1650 \mathrm{~cm}^{-1}$, respectively), Si-O stretching vibrations of $\mathrm{Si}-\mathrm{O}-\mathrm{Si}$ and $\mathrm{Si}-\mathrm{O}-\mathrm{Zr}$ fragments (1115-1170 and $1010-1050 \mathrm{~cm}^{-1}$, respectively), O-Si-O bending vibrations $\left(770-810 \mathrm{~cm}^{-1}\right), \mathrm{Zr}-\mathrm{O}$ stretching vibrations $600-700 \mathrm{~cm}^{-1}$ ) and lattice modes involving $\mathrm{Si}-\mathrm{O}-\mathrm{Si}$ bending vibrations and $\mathrm{H}_{2} \mathrm{O}$ libration (below $\left.550 \mathrm{~cm}^{-1}\right)$. 


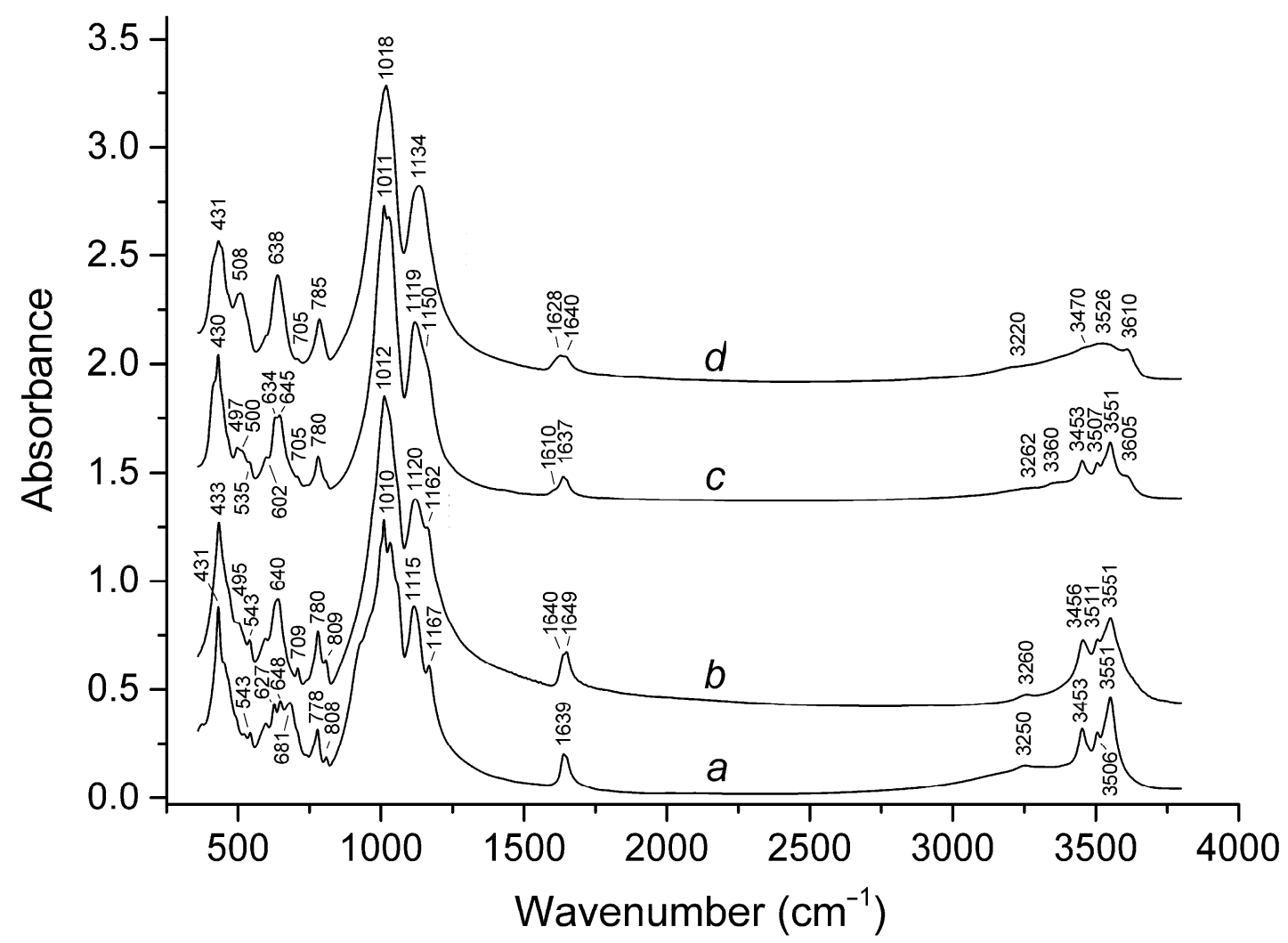

Figure 2. Powder infrared absorption spectra of (a) initial low-temperature elpidite from Lovozero, (b) initial rock-forming elpidite from Khan Bogdo, (c) Ag-exchanged elpidite from Lovozero (Sample I) and $(d)$ Ag-exchanged elpidite from Khan Bogdo (Sample II). The spectra are offset for comparison.

A specific and reproducible feature of low-temperature elpidite is a splitting of the bands of $\mathrm{Si}-\mathrm{O}$ and $\mathrm{Zr}-\mathrm{O}$ stretching vibrations of the $\mathrm{Si}-\mathrm{O}-\mathrm{Zr}$ fragments (the doublet $1010+1032$ and the triplet $627+648+681 \mathrm{~cm}^{-1}$, respectively). In the IR spectrum of elpidite from Khan Bogdo, single bands are observed in these ranges (at 1012 and $640 \mathrm{~cm}^{-1}$ ). These differences may be due to the different arrangement of $\mathrm{H}_{2} \mathrm{O}$ molecules in the structures of these elpidite varieties. According to the correlation $d_{\mathrm{D} \cdots \mathrm{A}}=0.1321 \times\left[26.44-\ln \left(3592-v_{\mathrm{O}-\mathrm{H}}\right)[18]\right.$, the strongest bands of $\mathrm{O}-\mathrm{H}$ stretching vibrations at 3453 , 3506 and $3551 \mathrm{~cm}^{-1}$ in the IR spectrum of initial elpidite from Lovozero correspond to the distances $d_{\mathrm{D} \cdots \mathrm{A}}$ between $\mathrm{O}$ atoms of water molecules and $\mathrm{H}$-bond donor atoms of 2.84, 2.91 and $3.00 \AA$, which is in good agreement with the structural data for this sample (see below). Relatively weak peaks at $3250-3260 \mathrm{~cm}^{-1}$ in the IR spectra of initial elpidite samples correspond to $\mathrm{H}_{2} \mathrm{O}$ molecules forming stronger H-bonds.

IR spectra of Ag-exchanged samples I and II in the range $360-1500 \mathrm{~cm}^{-1}$ are similar, but significant differences are observed in the high-frequency region. The spectrum of I contains six distinct bands of $\mathrm{O}-\mathrm{H}$ stretching vibrations (at 3605, 3551, 3507, 3453, 3360 and $3262 \mathrm{~cm}^{-1}$ ) and two bands of $\mathrm{H}-\mathrm{O}-\mathrm{H}$ bending vibrations (at 1637 and $1610 \mathrm{~cm}^{-1}$ ), which indicates the presence of at least three nonequivalent water molecules in this sample.

Bands of $\mathrm{H}_{2} \mathrm{O}$ stretching vibrations in the IR spectrum of II are broad and consist of numerous overlapping components, which reflects the chemical inhomogeneity of this sample.

\subsection{Dehydration and Rehydration Kinetics}

Thermogravimetric curves are given in Figure 3. In all samples except the initial sample from Khan Bogdo, dehydration starts at nearly $100^{\circ} \mathrm{C}$. The sample from Khan Bogdo shows anomalous behavior: its dehydration starts at $\sim 45^{\circ} \mathrm{C}$, and at $\sim 275^{\circ} \mathrm{C}$, an abrupt acceleration of weight loss is observed (Figure 3). These phenomena may be hypothetically explained by the fact that elpidite 
from Khan Bogdo crystallized as a water-poor phase at a higher temperature than the sample from Lovozero. In this case, its hydration could occur at lower temperatures (see data on $\mathrm{H}_{2} \mathrm{O}$-poor elpidite rehydration below). The total weight loss at $550{ }^{\circ} \mathrm{C}$ is equal to $10.16 \%$ for elpidite from Lovozero, $8.43 \%$ for elpidite from Khan Bogdo, 7.49\% for Sample II and 7.00\% for Sample I.

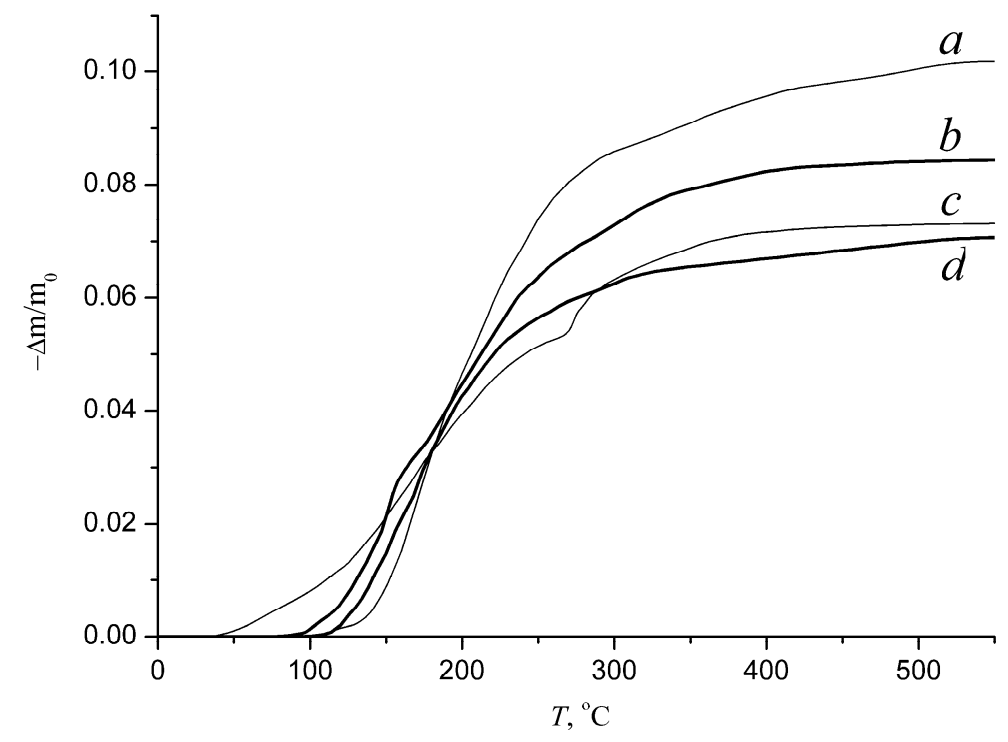

Figure 3. Thermogravimetric curves for (a) initial low-temperature elpidite from Lovozero, $(b)$ initial rock-forming elpidite from Khan Bogdo, (c) Ag-exchanged elpidite from Khan Bogdo (Sample II) and (d) Ag-exchanged elpidite from Lovozero (Sample I).

Kinetic data on rehydration (Figure 4) show that after elimination of one $\mathrm{H}_{2} \mathrm{O}$ molecule $p f u$, complete rehydration occurs in a humid air atmosphere during a period of three months. Rehydration of a completely dehydrated sample is a two-stage process. In the first stage, rapid sorption of water is followed by an induction period. After 40 days, sorption recommences. Most probably, during the induction period a structural transformation takes place which results in the broadening of zeolite channels [10].

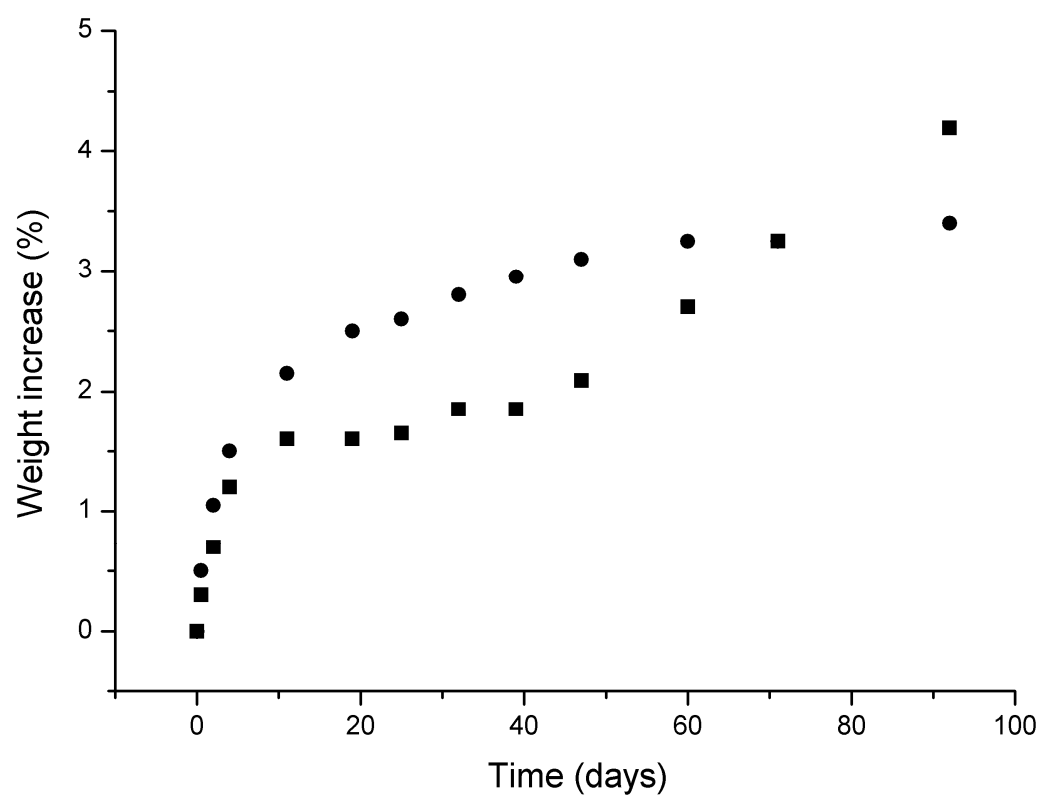

Figure 4. Kinetics of rehydration in humid air of completely (squares) and partly (to the degree of 50\%, circles) dehydrated elpidite from Lovozero. 


\subsection{X-Ray Diffraction Data and Crystal Structures}

All three studied structures retain the heteropolyhedral framework of elpidite consisting of double tetrahedral chains of $\mathrm{Si}_{6} \mathrm{O}_{15}$ which are linked by isolated $\mathrm{ZrO}_{6}$ octahedra to form the heteropolyhedral $\mathrm{Zr}-\mathrm{Si}-\mathrm{O}$ framework. In the structure of initial elpidite from Lovozero, $\mathrm{Na}$ cations and $\mathrm{H}_{2} \mathrm{O}$ molecules occupy positions in the voids of the heteropolyhedral framework. This structural model generally confirms the results obtained by [6]. The main difference between these models is that in our case one of two crystallographically non-equivalent Na sites is split. The Na1 site is split into the Na11 and Na12 sub-sites with partial occupancies of 0.45(2) for Na11 and 0.55(2) for Na12 and a Na11-Na12 distance of 0.834(9) $\AA$ that prevents their simultaneous filling. Na11 and Na12 sub-sites center eight- and seven-fold polyhedra, respectively. $\mathrm{Na} 2$ cations occupy $\mathrm{Na}_{2} \mathrm{O}_{4}\left(\mathrm{H}_{2} \mathrm{O}\right)_{2}$ octahedra. Atom coordinates and displacement parameters for initial elpidite from Lovozero are given in Table 4 and interatomic distances and hydrogen-bond geometry in Table 5.

Table 4. Atom coordinates and equivalent displacement parameters (in $\AA^{2}$ ) for initial elpidite from Lovozero.

\begin{tabular}{ccccc}
\hline Site & $x$ & $y$ & $z$ & $U_{\text {eq }}$ \\
\hline Zr & 0.5 & 0.5 & $0.3619(6)$ & $0.00597(16)$ \\
Si1 & $0.35828(7)$ & $0.90523(15)$ & $0.3600(9)$ & $0.0082(2)$ \\
Si2 & $0.3548(3)$ & $0.2214(4)$ & $-0.3624(3)$ & $0.0071(8)$ \\
Si3 & $0.3552(3)$ & $0.2228(4)$ & $0.0844(3)$ & $0.0095(8)$ \\
Na11 & 0.25 & $0.537(2)$ & $0.421(3)$ & $0.0324(13)$ \\
Na12 & 0.25 & $0.5367(19)$ & $0.303(3)$ & $0.0324(13)$ \\
Na2 & 0.5 & 0.5 & $-0.141(3)$ & $0.0196(6)$ \\
O1 & $0.3603(2)$ & $0.1926(5)$ & $-0.133(2)$ & $0.0134(8)$ \\
O2 & $0.4202(6)$ & $0.3797(10)$ & $0.1528(12)$ & $0.012(2)$ \\
O3 & $0.4202(6)$ & $0.3813(11)$ & $0.5690(13)$ & $0.016(2)$ \\
O4 & 0.25 & $0.2706(16)$ & $0.143(2)$ & $0.022(3)$ \\
O5 & $0.3803(8)$ & $0.0290(12)$ & $-0.4516(15)$ & $0.019(3)$ \\
O6 & $0.3822(7)$ & $1.0226(10)$ & $0.1782(16)$ & $0.018(3)$ \\
O7 & 0.25 & $0.2664(16)$ & $0.576(2)$ & $0.021(4)$ \\
O8 & 0.25 & $0.8579(7)$ & $0.358(3)$ & $0.0272(15)$ \\
O9 & $0.4117(2)$ & $0.7189(4)$ & $0.3685(16)$ & $0.0137(7)$ \\
Ow1 & $0.4202(3)$ & $0.7750(6)$ & $-0.133(2)$ & $0.0289(11)$ \\
H1a & 0.4006 & 0.8393 & -0.2373 & $0.043 *$ \\
H1b & 0.4006 & 0.8393 & -0.0373 & $0.043 *$ \\
Ow2 & 0.25 & $0.6213(15)$ & $0.7385(13)$ & $0.054(2)$ \\
H2 & $0.2028(9)$ & $0.637(13)$ & $0.807(5)$ & $0.081 *$ \\
\hline & & $* U_{\text {iso. }}$ & & \\
\hline & & & &
\end{tabular}

In both Ag-exchanged forms of elpidite, $\mathrm{ZrO}_{6}$ octahedra in the heteropolyhedral framework are significantly twisted relative to each other. These distortions and the arrangement of the extra-framework cations result in 14-14-14 $\AA$ unit cells. This phenomenon was previously reported for dehydrated elpidite and some cation-exchanged forms of the mineral (Table 1). Atom coordinates for Ag-exchanged forms of elpidite are given in Table 6 and selected interatomic distances in Table 7. 
Table 5. Selected interatomic distances $(\AA)$ and H-bonding in the structure of initial elpidite from Lovozero.

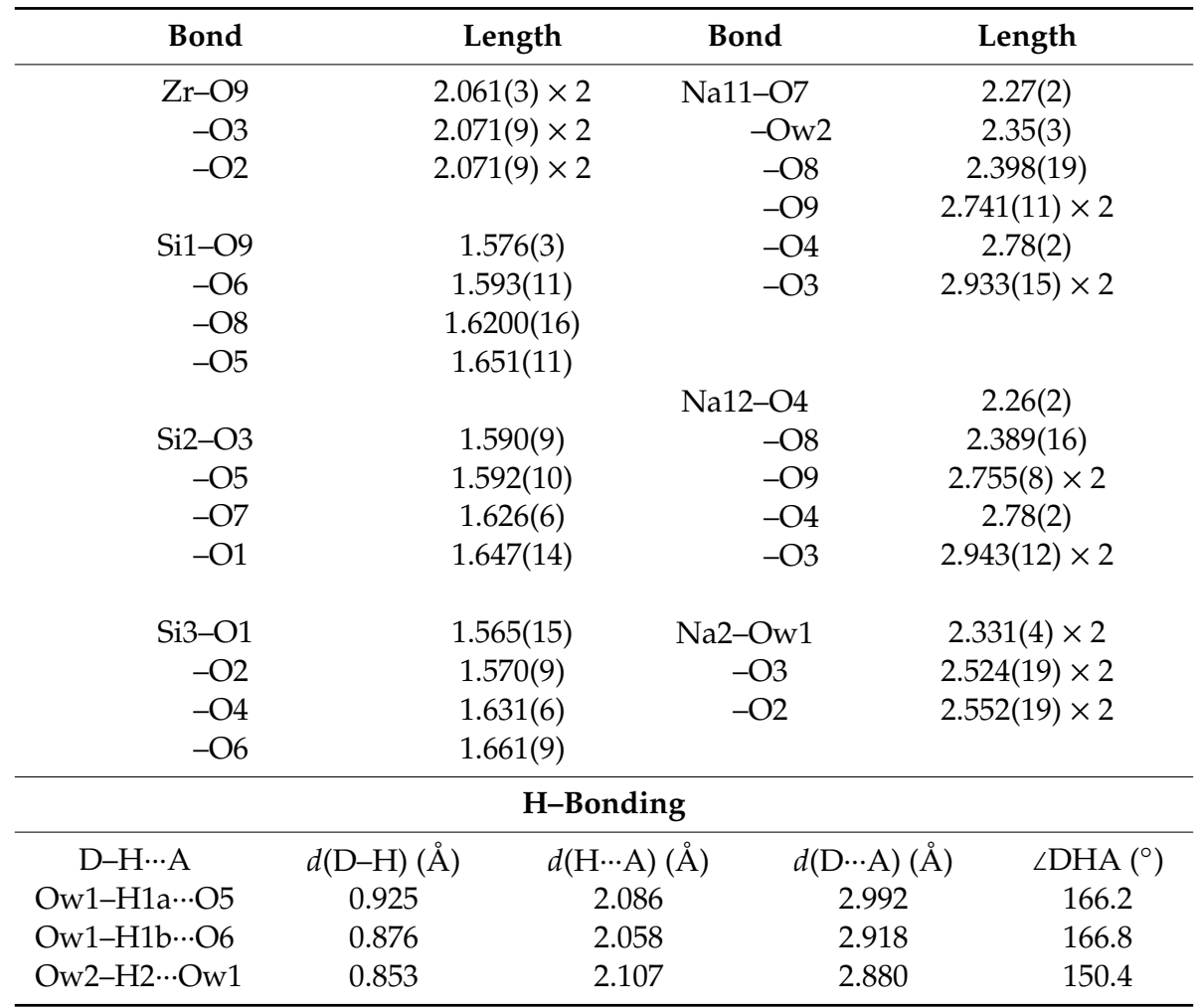

Note: $\mathrm{D}$ is $\mathrm{O}$ atom of the $\mathrm{H}_{2} \mathrm{O}$ molecule which is donor of the H-bond; $\mathrm{A}$ is $\mathrm{O}$ atom which is acceptor of the $\mathrm{H}$-bond. $\angle \mathrm{DHA}$ is the angle between the $\mathrm{D}-\mathrm{H}$ and $\mathrm{H} \cdots \mathrm{A}$ bonds.

Table 6. Atom coordinates, equivalent displacement parameters (in $\AA^{2}$ ) and site occupancy factors (s.o.f.) for Ag-exchanged forms of elpidite. The data for sample I and II are given in the first and the second lines of each row, respectively.

\begin{tabular}{cccccc}
\hline Site & $x$ & $y$ & $z$ & $U_{\text {eq }}$ & s.o.f. \\
\hline \multirow{2}{*}{ Zr } & 0.25 & 0.25 & 0.5 & $0.0068(3)$ & \multirow{2}{*}{ ( } \\
& 0.25 & 0.25 & 0.5 & $0.0049(2)$ & 1 \\
Si1 & $0.39106(12)$ & $0.09674(14)$ & $0.37813(13)$ & $0.0087(4)$ & 1 \\
& $0.39092(13)$ & $0.09659(13)$ & $0.37839(14)$ & $0.0083(4)$ & \\
Si2 & $0.38918(13)$ & $0.38122(14)$ & $0.66004(13)$ & $0.0091(4)$ & 1 \\
& $0.38874(13)$ & $0.38052(13)$ & $0.66137(14)$ & $0.0080(4)$ & \\
Si3 & $0.23591(13)$ & $0.04900(15)$ & $0.64023(13)$ & $0.0093(4)$ & 1 \\
& $0.23511(13)$ & $0.04904(12)$ & $0.64087(13)$ & $0.0079(4)$ & \\
O1 & $0.1674(3)$ & $0.1972(4)$ & $0.3929(3)$ & $0.0156(12)$ & 1 \\
& $0.1677(4)$ & $0.1968(4)$ & $0.3926(4)$ & $0.0163(11)$ & \\
O2 & $0.1444(3)$ & $0.0177(4)$ & $0.3690(4)$ & $0.0202(13)$ & 1 \\
& $0.1437(4)$ & $0.0170(4)$ & $0.3673(4)$ & $0.0167(11)$ & \\
O3 & 0.25 & $0.0754(6)$ & 0.75 & $0.0213(18)$ & 1 \\
& 0.25 & $0.0756(5)$ & 0.75 & $0.0171(16)$ & \\
O4 & $0.2166(3)$ & $0.1406(4)$ & $0.5848(3)$ & $0.0143(11)$ & 1 \\
& $0.2154(4)$ & $0.1412(3)$ & $0.5844(4)$ & $0.0133(10)$ & \\
O5 & 0.0 & $0.1253(6)$ & $0.3655(5)$ & $0.0183(18)$ & 1 \\
& 0.0 & $0.1272(5)$ & $0.3637(6)$ & $0.0151(16)$ & \\
O6 & $0.3283(3)$ & $-0.0060(4)$ & $0.6071(3)$ & $0.0173(12)$ & 1 \\
& $0.3279(4)$ & $-0.0054(4)$ & $0.6064(4)$ & $0.0153(11)$ & \\
\hline
\end{tabular}


Table 6. Cont

\begin{tabular}{cccccc}
\hline Site & $x$ & $y$ & $z$ & $U_{\text {eq }}$ & s.o.f. \\
\hline \multirow{2}{*}{ O7 } & $0.3747(3)$ & $0.3671(4)$ & $0.7715(3)$ & $0.0184(12)$ & 1 \\
& $0.3735(4)$ & $0.3666(4)$ & $0.7729(4)$ & $0.0172(12)$ & \\
O8 & $0.3655(3)$ & $0.1763(4)$ & $0.4494(3)$ & $0.0142(12)$ & 1 \\
& $0.3677(4)$ & $0.1762(4)$ & $0.4513(4)$ & $0.0138(11)$ & \\
O9 & 0.5 & $0.0640(5)$ & $0.3884(5)$ & $0.0156(17)$ & 1 \\
& 0.5 & $0.0631(5)$ & $0.3864(6)$ & $0.0140(15)$ & $0.80(2)$ \\
Ag1 & 0.5 & $0.2163(6)$ & $0.5428(3)$ & $0.0422(16)$ & $0.851(4)$ \\
& 0.5 & $0.2106(12)$ & $0.5471(9)$ & $0.0256(17)$ & $0.517(7)$ \\
Ag11 & 0.5 & $0.249(4)$ & $0.498(4)$ & $0.0422(16)$ & $0.040(7)$ \\
& 0.5 & $0.233(2)$ & $0.533(3)$ & $0.0256(17)$ & $0.19(4)$ \\
Ag11a & - & - & - & - & - \\
& 0.5 & $0.252(2)$ & $0.493(3)$ & $0.0256(17)$ & $0.053(6)$ \\
Ag12 & 0.5 & $0.178(5)$ & $0.558(3)$ & $0.0422(16)$ & $0.07(2)$ \\
& - & - & - & - & - \\
Ag13 & 0.5 & $0.3530(13)$ & $0.4040(14)$ & $0.0422(16)$ & $0.081(4)$ \\
& 0.5 & $0.3634(16)$ & $0.4148(16)$ & $0.0256(17)$ & $0.055(3)$ \\
Ag14 & $0.542(2)$ & $0.164(2)$ & $0.578(2)$ & $0.0422(16)$ & $0.0280(19)$ \\
& $0.5187(7)$ & $0.1688(11)$ & $0.5736(11)$ & $0.0256(17)$ & $0.068(3)$ \\
Ag15 & 0.5 & $0.332(2)$ & $0.370(2)$ & $0.0422(16)$ & $0.053(4)$ \\
& 0.5 & $0.3352(12)$ & $0.3866(12)$ & $0.0256(17)$ & $0.069(3)$ \\
Ag2 & 0.25 & $0.2393(4)$ & 0.75 & $0.0206(19)$ & $0.69(5)$ \\
& 0.25 & $0.23686(7)$ & 0.75 & $0.0202(4)$ & $0.743(5)$ \\
Ag21 & $0.273(3)$ & $0.231(2)$ & $0.753(2)$ & $0.0206(19)$ & $0.09(3)$ \\
& - & - & - & - & - \\
Ow1 & 0.0 & 0.0 & 0.5 & $0.051(7) *$ & $0.5 * *$ \\
& - & - & - & - & - \\
Ow11 & 0.0 & $0.039(3)$ & $0.527(3)$ & $0.051(7) *$ & $0.25 * *$ \\
Ow2 & 0.0 & $0.0201(9)$ & $0.5147(10)$ & $0.010(3) *$ & $0.5 * *$ \\
& $0.5261(12)$ & $0.3549(12)$ & $0.1934(11)$ & $0.064(8)$ & $0.435 * *$ \\
& & $* .3569(12)$ & $0.1954(19)$ & $0.080(10)$ & $0.43 * *$ \\
\hline & & $* * *$ Fixed during the refinement. & & \\
& & & & &
\end{tabular}

In both Ag-exchanged samples, extra-framework cations show a high degree of disorder: there are eight Ag sites in I and seven Ag sites in II and all of them are characterized by partial occupancies. In both structures, there are two main extra-framework sites which have similar coordinates and are characterized by the site occupancy factors (s.o.f.) of 0.80 (Ag1) and 0.69 (Ag2) (I), and 0.51 (Ag1) and 0.74 (Ag2) (II) [in both cases, the Ag scattering curve was used for the refinement]. In Sample I, both sites are further split, occupying sub-sites close to the main ones with very low s.o.f. In Sample II, only the $\operatorname{Ag}(1)$ site is characterized by further splitting. Bond valence calculations (the parameters were taken from [19]) performed on the Ag sites with s.o.f. of more than $10 \%$ gave the following bond valence sums (BVS) (all calculations were performed taking into account site occupancies): Ag1 (s.o.f. 0.80) BVS 0.84, Ag2 (s.o.f. 0.69) BVS 0.66 (sample I); Ag1 (s.o.f. 0.51) BVS 0.56, Ag11 (s.o.f. 0.19) BVS 0.23, Ag2 (s.o.f. 0.74) BVS 0.76 (sample II). During the refinement, the anisotropic displacement parameters were constrained to be equal for the main Ag sites and sub-sites formed as a result of their splitting. Due to some discrepancy between the water contents according to TG and structural data, we assume that some $\mathrm{H}_{2} \mathrm{O}$ molecules should be incorporated into slightly occupied $\mathrm{Ag}$ sites in both samples. Moreover, the Ag13 and Ag15 sites characterized by low occupancy are close to the $\mathrm{H}_{2} \mathrm{O}$ molecule position in initial elpidite and partially dehydrated elpidite [11] and thus, we assume that these sites also host $\mathrm{H}_{2} \mathrm{O}$ molecules, possibly as a dominant component. Due to this reason, these sites are included in Table 7 as ligands to "main" Ag sites. 
Table 7. Selected interatomic distances $(\AA)$ in the structures of Ag-exchanged forms of elpidite (samples I and II). For extra-framework cations, the distances are given only for the sites with s.o.f. higher than 10\%. The Ag13 and Ag15 sites are involved in the coordination spheres of other Ag sites due to the assumption that at these sites, $\mathrm{H}_{2} \mathrm{O}$ molecules dominate over Ag.

\begin{tabular}{|c|c|c|c|c|c|c|c|}
\hline \multicolumn{4}{|c|}{ Sample I } & \multicolumn{4}{|c|}{ Sample II } \\
\hline Bond & Length & Bond & Length & Bond & Length & Bond & Length \\
\hline Zr1-O4 & $2.062(5) \times 2$ & & & Zr1-O4 & $2.054(5) \times 2$ & Ag1-Ow2 & $2.37(3)$ \\
\hline$-\mathrm{O} 1$ & $2.075(5) \times 2$ & & & $-\mathrm{O} 1$ & $2.077(5) \times 2$ & $-\mathrm{O} 8$ & $2.373(8) \times 2$ \\
\hline$-\mathrm{O} 8$ & $2.090(5) \times 2$ & & & -08 & $2.102(5) \times 2$ & $-\mathrm{O} 5$ & $2.690(15)$ \\
\hline & & Ag1-O8 & $2.399(5) \times 2$ & & & $-\mathrm{O} 1$ & $2.863(9) \times 2$ \\
\hline $\mathrm{Si1}-\mathrm{O} 8$ & $1.589(5)$ & -Ow2 & $2.420(17)$ & Si1-O8 & $1.595(5)$ & $-A g 13$ & 2.92(3) \\
\hline$-\mathrm{O} 6$ & $1.612(5)$ & $-\mathrm{O} 5$ & $2.663(10)$ & $-\mathrm{O} 6$ & $1.617(5)$ & $-A g 15$ & $2.93(3)$ \\
\hline$-\mathrm{O} 9$ & $1.624(3)$ & $-A g 13$ & $2.82(2)$ & $-\mathrm{O} 7$ & $1.621(6)$ & & \\
\hline$-\mathrm{O} 7$ & $1.630(5)$ & $\begin{array}{l}-\mathrm{O} 1 \\
-A g 15\end{array}$ & $\begin{array}{c}2.843(6) \times 2 \\
3.00(3)\end{array}$ & $-\mathrm{O} 9$ & $1.622(3)$ & $\begin{array}{r}\mathrm{Ag} 11-\mathrm{O} 8 \\
-\mathrm{O} 5\end{array}$ & $\begin{array}{c}2.36(2) \times 2 \\
2.52(3)\end{array}$ \\
\hline $\mathrm{Si} 2-\mathrm{O} 1$ & $1.592(5)$ & & & Si2-O1 & $1.583(5)$ & $-A g 13$ & $2.55(5)$ \\
\hline$-\mathrm{O} 2$ & $1.608(6)$ & & & $-\mathrm{O} 2$ & $1.617(6)$ & $-A g 15$ & $2.57(5)$ \\
\hline$-\mathrm{O} 5$ & $1.615(2)$ & Ag2-O3 & $2.398(10)$ & $-\mathrm{O} 5$ & $1.618(3)$ & $-\mathrm{Ow} 2$ & $2.69(5)$ \\
\hline$-\mathrm{O} 7$ & $1.619(5)$ & $\begin{array}{l}-\mathrm{O} 1 \\
-\mathrm{O} 7\end{array}$ & $\begin{array}{l}2.531(5) \times 2 \\
2.591(7) \times 2\end{array}$ & $-\mathrm{O} 7$ & $1.622(6)$ & $-\mathrm{O} 1$ & $2.795(17) \times 2$ \\
\hline $\mathrm{Si} 3-\mathrm{O} 4$ & $1.581(5)$ & $-\mathrm{O} 4$ & $2.808(6) \times 2$ & $\mathrm{Si3}-\mathrm{O} 4$ & $1.593(5)$ & Ag2-O3 & $2.354(8)$ \\
\hline$-\mathrm{O} 6$ & $1.608(5)$ & & & $-\mathrm{O} 6$ & $1.611(5)$ & $-\mathrm{O} 1$ & $2.540(6) \times 2$ \\
\hline$-\mathrm{O} 3$ & $1.628(3)$ & & & $-\mathrm{O} 2$ & $1.617(5)$ & $-\mathrm{O} 7$ & $2.597(6) \times 2$ \\
\hline$-\mathrm{O} 2$ & $1.629(5)$ & & & $-\mathrm{O} 3$ & $1.622(3)$ & $-\mathrm{O} 4$ & $2.792(5) \times 2$ \\
\hline
\end{tabular}

The structures of both Ag-exchanged samples are shown in Figure 5.

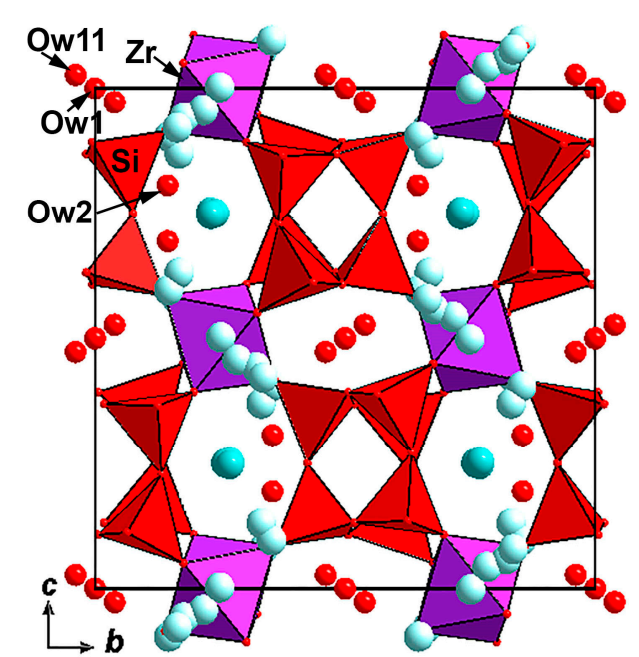

(a)

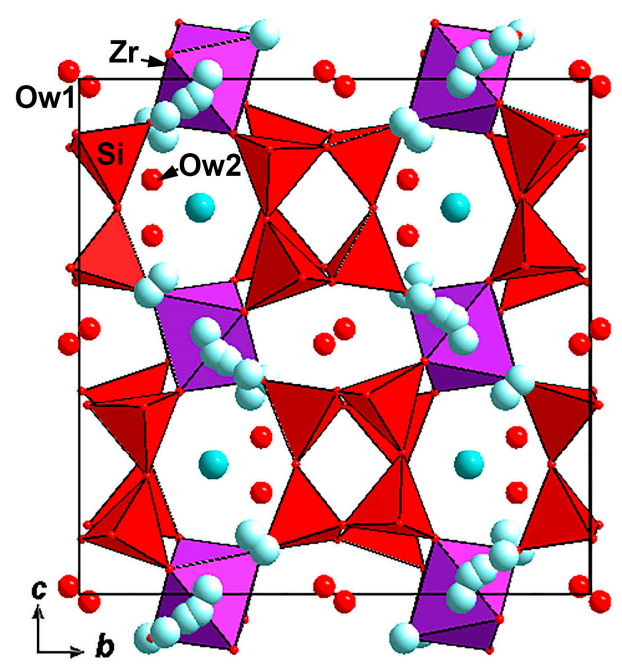

(b)

Figure 5. The crystal structures of Ag-exchanged forms of elpidite projected along the $a$ axis: Sample I (a) and Sample II (b). The Ag1 site and its sub-sites are light blue circles; the Ag2 site and its subsites (I) are blue circles. The unit cells are outlined.

For the comparison of the positions of extra-framework sites in initial samples and Ag-exchanged forms of elpidite, we have used the models of initial elpidite from Lovozero (this work) (Figure 6a-c) and elpidite from Khan Bogdo [3] (Figure 6d-f), taking into account only the positions of the mainly Ag-occupied sites in Ag-exchanged forms for better clarity. The structure of Sample II is shown in Figure $6 \mathrm{~g}-\mathrm{i}$. 


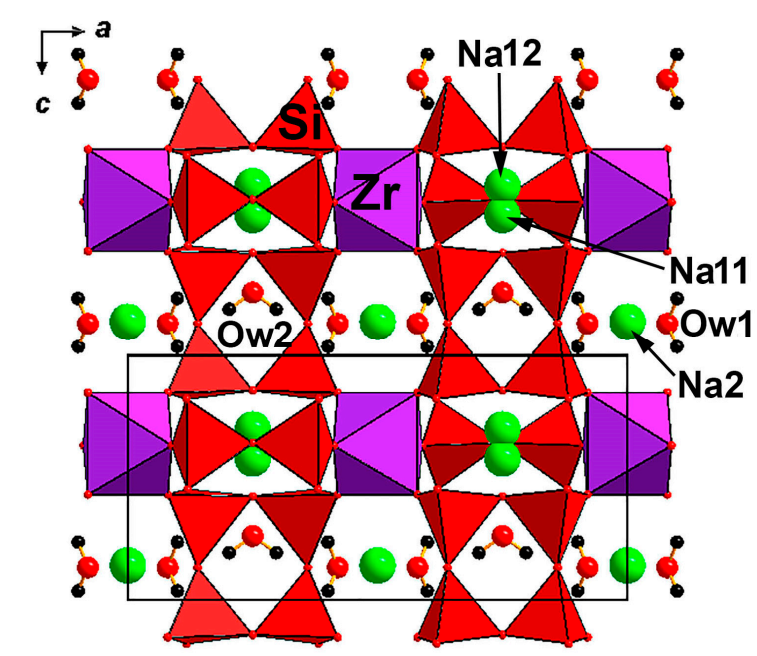

(a)

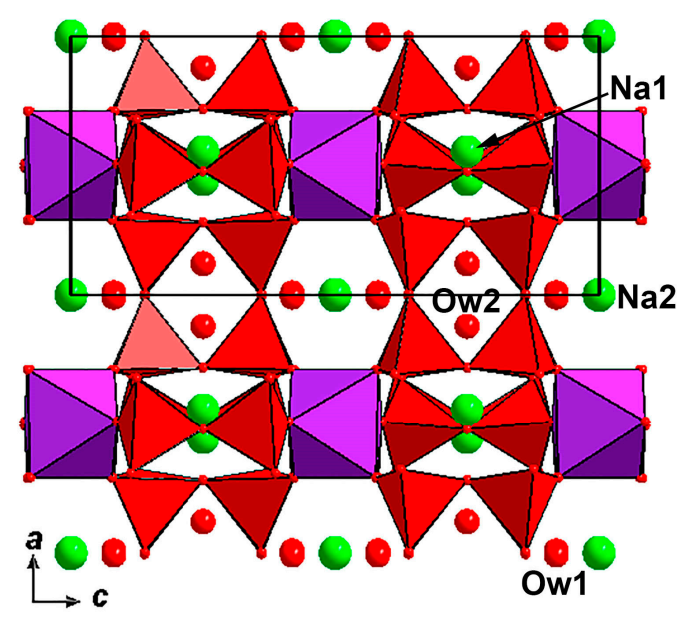

(d)

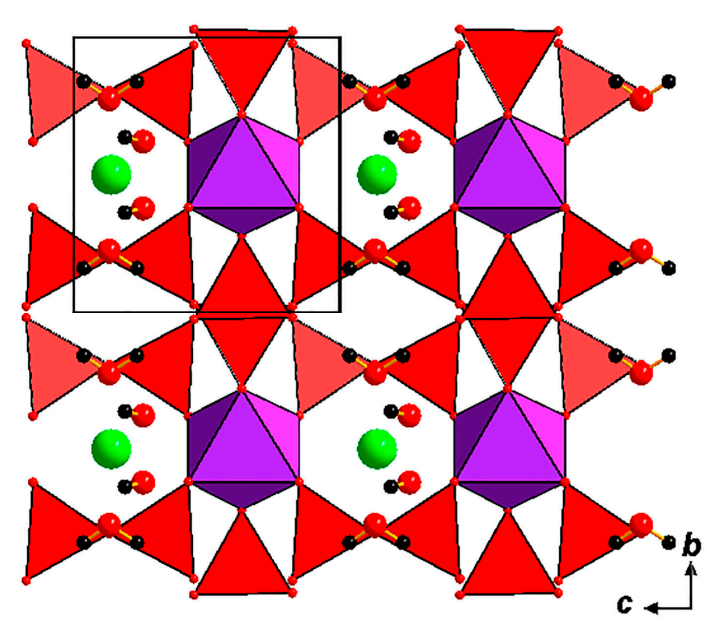

(b)

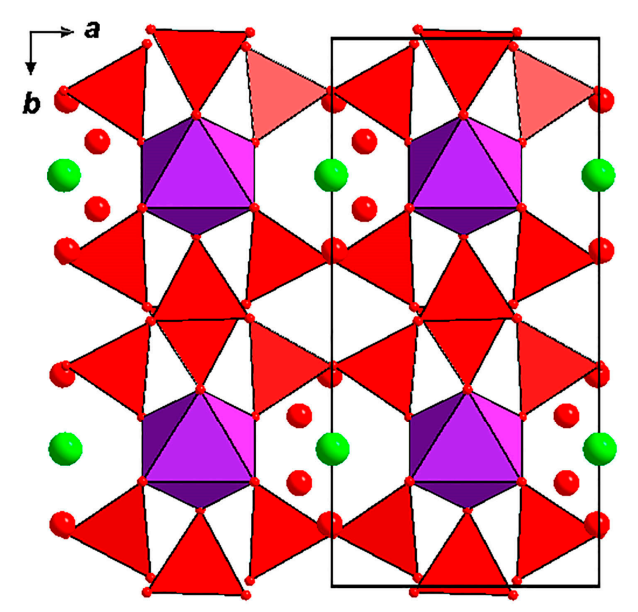

(e)

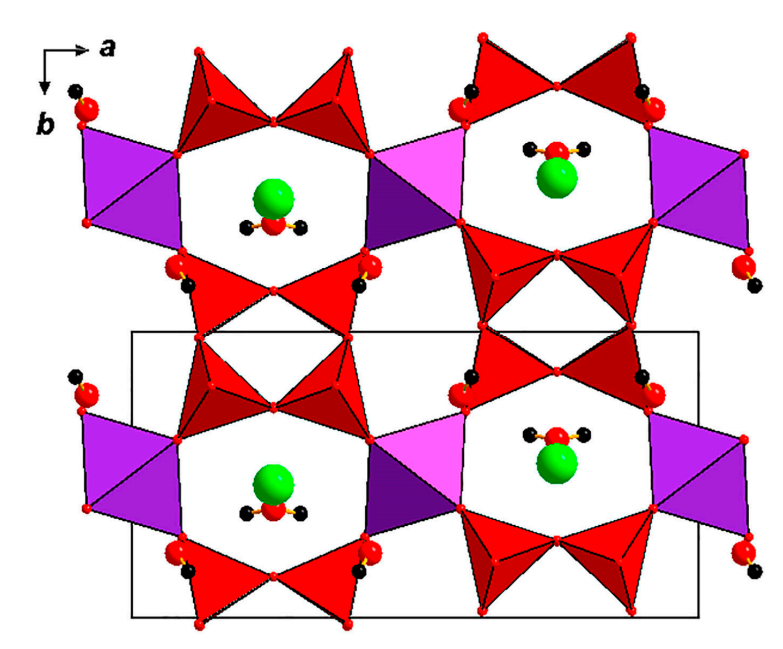

(c)

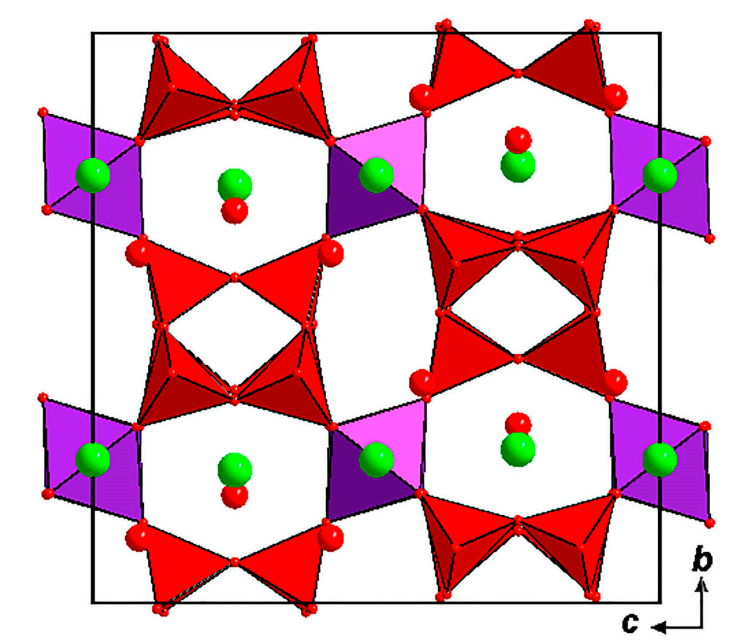

(f)

Figure 6. Cont. 


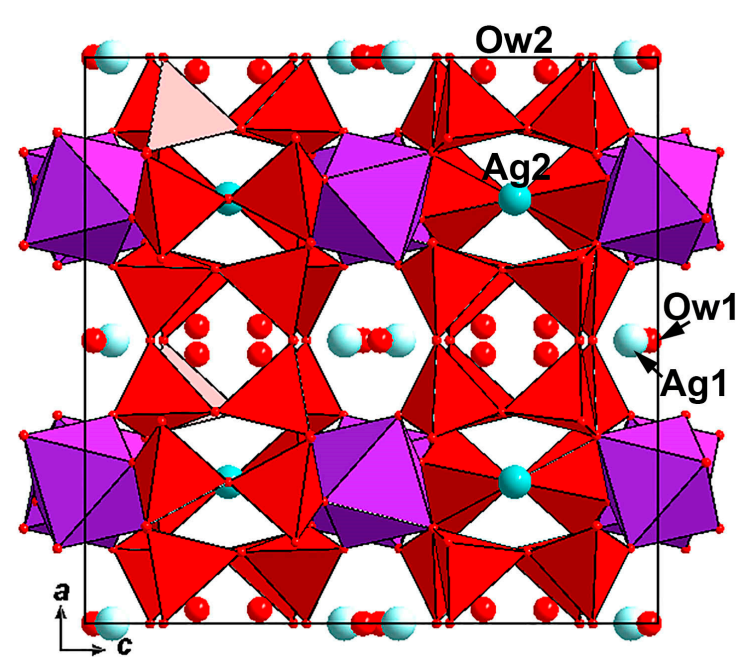

(g)

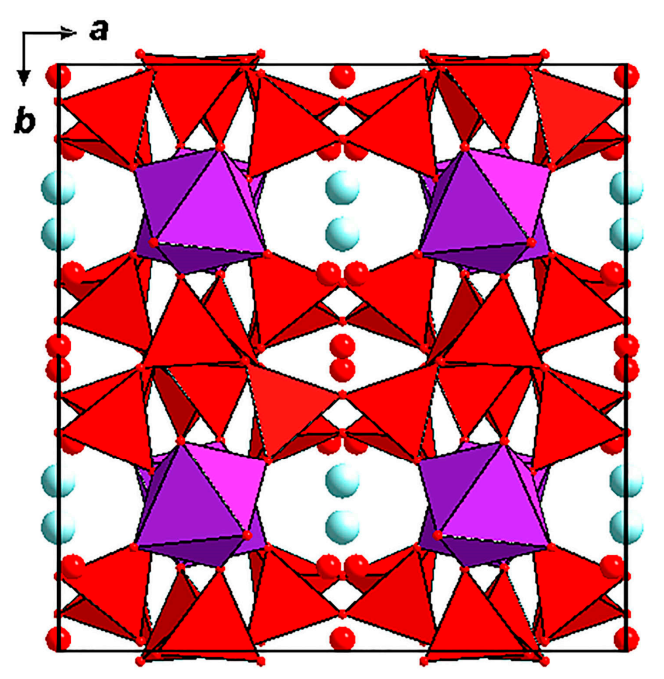

(h)

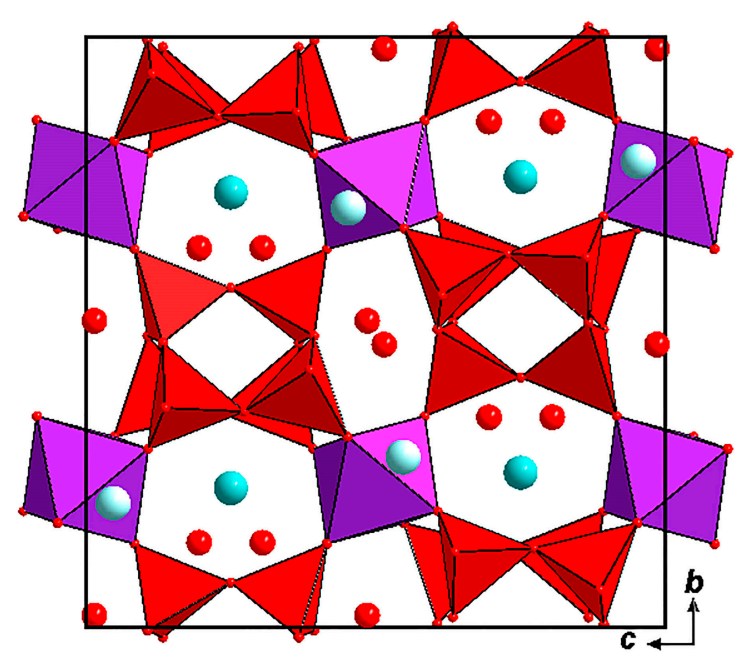

(i)

Figure 6. The crystal structures in three projections of: initial elpidite from the Lovozero alkaline massif (a-c), initial elpidite from Khan Bogdo (drawn after [3]) (d-f) and Ag-exchanged form of elpidite from Khan Bogdo [only the main Ag sites are shown] (g-i). The unit cells are outlined. 
The Ag1 site is located between an $\mathrm{H}_{2} \mathrm{O}$ molecule and the $\mathrm{Na} 2$ site in initial elpidite. The Ag2 site in Ag-exchanged samples corresponds to the Na1 site in initial elpidite. In both structures of Ag-exchanged forms of the mineral, the Ag1 site also corresponds to the Na1 site in the partially dehydrated elpidite [11] and Na1 in completely dehydrated elpidite in which this site is additionally split $[10,11]$. The Ag2 site corresponds to the $\mathrm{Na} 2$ position in both partially and completely dehydrated elpidite samples [10,11]. The location of Ow11 in both Ag-exchanged forms of elpidite (and of Ow1 in I) is close but not identical to the Ow1 site in partially dehydrated elpidite. In samples I and II, this $\mathrm{H}_{2} \mathrm{O}$ position is shifted to the centre of the channel running along the $a$ axis which is empty in other known elpidite structure models, as well as in 14-14-14 $\AA$ cation-exchanged and dehydrated forms (except the K-exchanged form obtained at $90^{\circ} \mathrm{C}$ in which this channel hosts sites of $\mathrm{K}$ cations with a very low occupancy). The Ow2 site in I and II almost exactly corresponds to the Ow11 site in the structure of partially dehydrated elpidite [11]. The position of the Ag1 site in both I and II are close to the most occupied $\mathrm{Rb}$ site in the Rb-exchanged (at $150{ }^{\circ} \mathrm{C}$ ) form and to the most occupied $\mathrm{K}$ site in both (obtained at $90^{\circ} \mathrm{C}$ and $150^{\circ} \mathrm{C}$ ) K-exchanged forms of elpidite [3]. It is important to highlight that the Ag2 site predominantly occupied by Ag in samples I and II retains only a minor amount of $\mathrm{Na}$ in the structures of $\mathrm{K}$ - and $\mathrm{Rb}$-exchanged forms of elpidite and does not contain exchanged $\mathrm{K}$ or $\mathrm{Rb}$ cations. It was assumed that the zeolitic cavity that includes this $\mathrm{Na}(1)$ site at the center of an eight-fold polyhedron has insufficient space to accommodate cations larger than $\mathrm{Na}^{+}$[3]. However, this site is able to host exchanged $\mathrm{Ag}^{+}$due to the fact that $\mathrm{Na}^{+}$and $\mathrm{Ag}^{+}$cations have similar ionic radii [20].

\section{Discussion}

Elpidite from both Lovozero and Khan Bogdo demonstrates a high exchange capacity to $\mathrm{Ag}^{+}$. The cation exchange is accompanied by a significant distortion of the heteropolyhedral framework, which results in the doubling of the $\sim 7 \AA$ parameters of the unit cell and the change in symmetry from space groups Pma2 or $\mathrm{Pbcm}$ (characteristic to the initial elpidite samples) to Cmce. Similar structural transformations were found earlier for the product of thermal dehydration of elpidite and for $\mathrm{K}$ - and $\mathrm{Rb}$-exchanged forms of this mineral. At the same time, the mechanism of exchange of $\mathrm{Na}^{+}$for $\mathrm{Ag}^{+}$in elpidite apparently differs from that in the cases of $\mathrm{K}^{+}$and $\mathrm{Rb}^{+}$exchange: in the latter cases, exchanged large cations incorporate into the site initially occupied by an $\mathrm{H}_{2} \mathrm{O}$ molecule in the most voluminous zeolitic cavity rather than into the site of the $\mathrm{Na}^{+}$cation. Thus, the occurrence of preferential exchange of $\mathrm{K}^{+}$and $\mathrm{Rb}^{+}$cations at the sites occupied by $\mathrm{H}_{2} \mathrm{O}$ molecules in initial samples explains the drastic decrease in the water content in both $\mathrm{K}$ - and $\mathrm{Rb}$-exchanged forms of elpidite. In contrast to this, exchanged $\mathrm{Ag}^{+}$cations preferably occupy the sites that are close to the $\mathrm{Na}$ sites in the initial elpidite and correspond to the Na sites in the product of elpidite dehydration characterized by similar unit cell parameters with Ag-exchanged samples. Moreover, a site at the center of the channel running along the $a$ axis, which is considered as an $\mathrm{H}_{2} \mathrm{O}$ molecule position, was found in both Ag-exchanged samples. This results in the higher water content in Ag-exchanged elpidite as compared to K- and Rb-exchanged forms.

The rehydration processes, with the duration of several tens of days, cannot be related to the surface of crystals because adsorption is a rapid process. Moreover, the specific surface of the samples used was too small, and thereby excludes much of the percentage adsorption of $\mathrm{H}_{2} \mathrm{O}$. Earlier, it was shown by us [10] that dehydration of elpidite is accompanied by a structural transformation involving the narrowing of channels. Consequently, a reverse process (i.e., hydration) should be accompanied by a structural transformation involving the widening of channels. This may be the cause of the observed acceleration of rehydration of the initially anhydrous sample after an induction period (Figure 4).

Author Contributions: N.V.Z., N.V.C., I.V.P., V.V.K.-K. and D.Y.P. wrote the paper. R.P.N., N.V.Z. and O.N.K. solved and refined the crystal structure. G.V.S. obtained single-crystal XRD data on the Ag-exchanged sample from Khan Bogdo. N.V.C. obtained and analyzed IR spectra and carried out rehydration experiments. D.A.V. obtained chemical data. T.S.L. obtained TG data on dehydration of initial and exchanged samples. N.A.C., N.V.C. and V.V.K.-K. carried out ion-exchange experiments. 
Funding: This work was supported by the Russian Foundation for Basic Research, grants nos. 18-29-12007-mk (determination of chemical composition, IR spectroscopic and TG data, crystal chemical analysis) and 18-55-18003 - together with the National Science Fund of Bulgaria under the contract No. DNTS/Russia 02/8 from 15.06.2018 (ion-exchange experiments, single crystal X-ray diffraction data and determination of the crystal structures).

Conflicts of Interest: The authors declare no conflict of interest.

\section{References}

1. Chukanov, N.V.; Pekov, I.V.; Rastsvetaeva, R.K. Crystal chemistry, properties and synthesis of microporous silicates containing transition elements. Russ. Chem. Rev. 2004, 73, 227-246. [CrossRef]

2. Turchkova, A.G.; Pekov, I.V.; Bryzgalov, I.A. Cation-exchange properties of natural zeolite-like sodium zirconosilicates: An experimental study in aqueous solutions at $80-90{ }^{\circ} \mathrm{C}$ and $1 \mathrm{~atm}$. In Proceedings of the 19th General Meet of IMA, Kobe, Japan, 23-28 July 2006.

3. Grigor'eva, A.A.; Zubkova, N.V.; Pekov, I.V.; Kolitsch, U.; Pushcharovsky, D.Y.; Vigasina, M.F.; Giester, G.; Đorðevic, T.; Tillmanns, E.; Chukanov, N.V. Crystal chemistry of elpidite from Khan Bogdo (Mongolia) and its K-and Rb-exchanged forms. Crystallogr. Rep. 2011, 56, 832-841. [CrossRef]

4. Salvi, S.; Williams-Jones, A.E. Zirconosilicate phase relations in the Strange Lake (Lac Brisson) Pluton, Quebec-Labrador, Canada. Amer. Mineral. 2001, 13, 355-363. [CrossRef]

5. Neronova, N.N.; Belov, N.V. Crystal structure of elpidite $\mathrm{Na}_{2} \mathrm{ZrSi}_{6} \mathrm{O}_{15} \cdot\left(\mathrm{H}_{2} \mathrm{O}\right)_{3}$. Dimorphism of the dimetasilicate radical $\mathrm{Si}_{6} \mathrm{O}_{15}$. Dokl. Akad. Nauk SSSR 1963, 150, 642-645. (In Russian)

6. Neronova, N.N.; Belov, N.V. Crystal structure of elpidite, $\mathrm{Na}_{2} \mathrm{ZrSi}_{6} \mathrm{O}_{15} \cdot\left(\mathrm{H}_{2} \mathrm{O}\right)_{3}$. Sov. Phys. Crystallogr. 1964, 9, 700-705.

7. Cannillo, E.; Rossi, G.; Ungaretti, L. The crystal structure of elpidite. Am. Mineral. 1973, 58, 106-109.

8. Sapozhnikov, A.N.; Kashaev, A.A. Features of the crystal structure of calcium-containing elpidite. Sov. Phys. Crystallogr. 1978, 23, 24-27.

9. Sapozhnikov, A.N.; Kashaev, A.A. The crystal structure of calcined Ca-containing elpidite. Sov. Phys. Crystallogr. 1980, 25, 357-359.

10. Zubkova, N.V.; Ksenofontov, D.A.; Kabalov, Y.K.; Chukanov, N.V.; Nedel'ko, V.V. Dehydration-induced structural transformations of the microporous zirconosilicate elpidite. Inorg. Mat. 2011, 47, 506-512. [CrossRef]

11. Cametti, G.; Armbruster, T.; Nagashima, M. Dehydration and thermal stability of elpidite: An in-situ single crystal X-ray diffraction study. Microporous Mesoporous Mat. 2016, 227, 81-87. [CrossRef]

12. Nedel'ko, V.V.; Chukanov, N.V.; Pekov, I.V. Dehydration kinetics of the microporous zirconosilicate elpidite. Inorg. Mat. 2011, 47, 502-505. [CrossRef]

13. Agakhanov, A.A.; Pautov, L.A.; Karpenko, V.Y.; Sokolova, E.; Abdu, Y.A.; Hawthorne, F.C.; Pekov, I.V.; Siidra, O.I. Yusupovite, $\mathrm{Na}_{2} \mathrm{Zr}\left(\mathrm{Si}_{6} \mathrm{O}_{15}\right)\left(\mathrm{H}_{2} \mathrm{O}\right)_{3}$, a new mineral species from the Darai-Pioz alkaline massif and its implications as a new microporous filter for large ions. Am. Mineral. 2015, 100, 1502-1508. [CrossRef]

14. Pekov, I.V. Lovozero Massif: History, Pegmatites, Minerals; OP: Moscow, Russia, 2000; p. 480.

15. Agilent Technologies, CrysAlisPro Software System, Version 1.171.35.21; Agilent Technologies: Santa Clara, CA, USA, 2012.

16. Rigaku Oxford Diffraction, CrysAlisPro Software System, Version 1.171.39.46; Rigaku Oxford Diffraction: Oxford, UK, 2018.

17. Sheldrick, G.M. Crystal structure refinement with SHELXL. Acta Cryst. 2015, 71, 3-8.

18. Libowitzky, E. Correlation of $\mathrm{O}-\mathrm{H}$ stretching frequencies and $\mathrm{O}-\mathrm{H} \cdots \mathrm{O}$ hydrogen bond lengths in minerals. Mon. für Chem. 1999, 130, 1047-1059.

19. Gagné, O.C.; Hawthorne, F.C. Comprehensive derivation of bond-valence parameters for ion pairs involving oxygen. Acta Cryst. 2015, 71, 562-578. [CrossRef] [PubMed]

20. Shannon, R.D. Revised effective ionic radii and systematic studies of interatomie distances in halides and chaleogenides. Acta Crystallogr. 1976, 32, 751-767. [CrossRef] 